\title{
Connotative Confluence: Imagery and its functions in Shakespeare's King Lear
}

\author{
Shazia Aziz \\ COMSATS University Islamabad, Lahore Campus, Pakistan \\ Rabia Ashraf \\ Lahore College for Women University, Lahore, Pakistan \\ Huma Ejaz \\ COMSATS University Islamabad, Lahore Campus, Pakistan \\ Rafi Amir-ud-Din \\ COMSATS University Islamabad, Lahore Campus, Pakistan
}

\section{Introduction}

Imagery refers to the 'set of images and relation of images'(Durand, 1999)which constitute the principal thought of humans and the purpose of these symbols in any text is the 'epiphany of mystery' by which we are able to visualize the 'invisible' through the glass of 'parables, myths and poems'(Durand et al., 1996).

Written prose employs images to heighten its effect (David, 1998). Human memory uses different agencies to recognize different natural phenomena and the use of images significantly helps memory in recalling the past events(Paivio et. al., 1968; Stenberg et. al., 1995) and commemorative pictorial representation is more meaningful than the verbal one(Hockley, 2008). Despite its popularity and extensive use in different contexts with different shades of meaning, imagery defies a systematic and rational explanation of its usage(Alex et. al., 1993) and image is often confused with other poetic devices like metaphor (Nadal, 1994).

Shakespeare's imagery is exceptionally vivid and makes a powerful impact on our minds and is the best possible manifestation of poetic faith. Some critics of Shakespearean tragedies link imagery with metaphors (Ellis-Fermor, 1980). 
Spurgeon (1935) terms both metaphors and similes as images and declares the images that play their part in the overall meaning making of a play as the most important.

As Spurgeon (1935)has it, the recurrent images in Shakespeare's tragedies have manifold functions: they are sometimes employed as a mere embellishment or to provide a tragic atmosphere, sometimes to heighten the emotion and sometimes to convey the idea of the grotesque or repellent, sometimes to establish binary opposites(Tung, 2010) and sometimes to beautify the form. They also help in building and developing the themes in the play like justice and trial, a repeated motif in King Lear (Hockey, 1959), appearance and reality, good and evil, human nature, man's plight, nature's reaction, death and so on. It also functions as a catalyst of pathos by heightening the tragic effect. Most importantly, it consistently provides a political commentary on the action and an indirect commentary on contemporary English politics. Sometimes, images are used to reflect and reverberate, revealing philosophical thought (Spurgeon, 1935).

The middle acts of King Lear, i.e., acts II and IV, are the richest in the utilization of imagery for portrayal of the inner psychological drama these acts are marked by. The outer action in these acts is pushed to the external fringes of the plot's underlying thought. The main emphasis is upon the action that surrounds the protagonist, Lear, and his predicament and the dilemma that unfolds gradually. Imagery proves to be a great form of expression for such an inner process helping in enhancement of the pathos of Lear's tragedy. Accordingly, the first act contains little nature-imagery; in the second act it begins to grow, and it attains its peak in the third and fourth acts which show us the forsaken Lear in madness. The use of imagery increases with Lear's increasing isolation in the human world (Clemen, 2013). This imagery gradually becomes more serious in invocation of resentment and indignation, suggesting Lear's destitute state of mind and dismal moral condition and points to his dreadful future. This paper focuses on the use of images by different characters as stylistic tools in their dialogues, tracing subsequently, the role of imagery drawn from different source domains to understand a higher Shakespearean truth in the play.

\section{The Major source domains of imagery in King Lear}

Shakespeare draws most of his images from either nature or indoor life (Spurgeon, 1935). Nature, animal world, daily indoor life, movement, clothing, food, justice and trial are the main sources from where imagery has been derived for King Lear. While nature imagery including that from England's country-side, changes in weather, the sky, astrology, garden, growth and decay, etc. is used primarily to depict the crisis faced by the characters, animal imagery helps to show man's position in 'the chain of being' (Spurgeon, 1935), to highlight the beastly and 'subhuman nature' of the evil characters; to show man's frailty as compared to animals; 
and to compare the lives of humans and animals of the wild. Animal imagery is exploited mostly through alimentary references (Sparer, 2009) or gustatory imagery which has been used to fulfill the literary fool's purpose of imparting wisdom and characterization through apparently nonsensical statements. It also helps provide political commentary on the dramatic action and establish certain identities through other enlightened characters and those who undergo enlightenment like Cordelia, Kent, Edgar, Albany, and Lear (Sparer, 2009). The motif of a food chain created by Shakespeare categorizes some dramatic personae as all-consumptive to the extent of cannibalism (the Machiavellian figures viz., Regan, Goneril, and Edmund), and others as their famished victims (the Lear camp i.e., Lear, Cordelia, Kent, and Edgar) thus offering various perspectives on the play's meaning and political relationships as outlined in 'Humanity must perforce prey on itself, / Like monsters of the deep'. (IV, ii, 3)

The prolific images related to the simple indoor activities like drinking, eating, cooking, wiping, cleaning, materials, fire, sickness, birth and death etc., have a great appeal to every common man among the audience and hence help them relate to the events happening in the play easily. The recurrent imagery related to movement, banging, fighting, torture, etc., flows naturally from emotional turmoil faced by Lear and creates in the audience a similar sensation. The images of clothing and nakedness are exploited to establish the fact that once humans are divested of the emblems of their social status, they are either worthless or are not distinguishable from one another. Imagery of justice, crime and punishment in several kinds of trials starting from the opening scene has been used to develop two major themes-love and justice- and to draw comparisons and contrasts between different characters and their development.

\section{Themes portrayed and Functions achieved through imagery in King Lear 3.1. Mental and Physical suffering and pain}

There is prolific use of images of several types of physical movement mostly involving physical and mental pain. The regretful Lear imagines an 'engine' wrenching and torturing him. He is pictured beating his head at the gate for letting folly in. He complains about Goneril having struck him with her tongue, shaking his manhood. He says his heart will break into a thousand flaws due to hot tears. Albany wonders at the possibility of Goneril's eyes being pierced. We also hear the mention of the cracking of Gloucester's 'flaw'd heart', and finally its bursting 'smilingly'. Kent's wish to tread Oswald into mortar, and his account of the character of the steward, using images of rats billing cords, weather cocks turning, dogs following and geese being driven provide a comparison of man with animals. Lear complains against the violent offence of putting Kent in the docks declaring it to be worse 'than murder'. His emotion on this sight 'swells and climbs'. The Fool pictures through imagery a man being dragged on to a great wheel running downhill, and his neck being saved from being broken by letting go just in time. 
Similarly, Edmund's argument in trying to restrain Gloucester from immediate action against Edgar is full of imagery. Edmund says if he suspends his resentment until he has better evidence of his intention, he should 'run a certain course' and if he violently proceeds against him, without knowing his purpose, it would cause a great 'gap' in his own honour and 'shake in pieces the heart of his obedience'. Gloucester, heart-broken by Edmund's revelations, uses many verbs including 'scourged', 'falls off', 'cools', 'divide', 'falls from', 'cracked', 'follow disquietly' and nouns like 'bias', 'discord', 'mutinies', 'hollowness', 'machinations', 'ruinous disorders', all suggestive of disturbed movement within ten lines.

The all-pervasive images of anguished motion are reinforced by parallel expressions explaining events directly e.g., in the account of Gloucester being bound to a chair, plucked by the beard, his hair ravished from his chin, when he is tied to a stake, like a bear to stand the course, and with his eyes blinded and bleeding, he is thrust out of the gates to smell his way, like an animal, to Dover. In the gentleman's description of Cordelia's reaction to his news, this strain is evident when we hear that the letters pierced her to a demonstration of grief and she started 'To deal with the grief alone' (IV.iii. 37)

This is in keeping with Shakespeare's love of movement which is one of the secrets of his exquisite style. This allows him to endow motionless and inanimate objects with life-like presence in the play.

Kent describes Lear's mental suffering in a succession of images of corporeal buffeting, opposition and pain when Lear's 'burning shame detains him from Cordelia'. These, along with the two images of poisonous serpents and brutal dogs have an overwhelmingly painful impact on the audiences' minds.

\subsection{Commentary on Human Nature}

The motif of unnatural terrors, of humans 'preying on themselves' monstrously, or tearing one another's flesh like tigers and wolves, is also constantly portrayed before us. Filial ingratitude is compared with the mouth tearing the hand. Gloucester says to Regan he sent Lear to Dover to avoid seeing her 'cruel nails pluck out his poor old eyes', or the brutal sister 'stick bearish fang' in his 'anointed flesh'. Likewise, Albany tells Goneril that she and Regan are tigers 'red in tooth and claw', affirming his belief that they are devoid of even the last vestiges of humanity.

\subsection{Man vs. Nature}

Lear commands the all shaking thunder to "smile flat the thick rotundity of the world'. This image evokes the sight of shattering bodily action on such a horrible scale that the emotions which give rise to it rise to a similar intensity. The audience is prepared for the picture that follows it: the picture of the great gods pitilessly seeking their enemies, through thunder, roaring wind and rain, while 'close pent-up guilts' rive their concealing continents and cry. 
The nature imagery in the play depicts Nature in its benevolent and malevolent aspects. Nature as a benign force binds all creatures together in their true relationships involving a harmonious co-existence, loyalty, co-operation and affection. Kent, Edgar, Lear and Gloucester are representatives of this belief about Nature. Edmund is a follower of Nature, his 'goddess' encouraging him to think only of the fulfillment of his own desires, declaring that his 'services are bound' to it. The malicious aspect of Nature is a force for Lear to compete. Lear gives the audience a graphic description of the storm by throwing a challenge at the winds, the thunder, the lightening, etc. to do their worst. Edgar gives a picturesque description of Nature when talking to his father. He gives an impression that he is standing at the top of the cliff to which he wanted to be led and he tells him that standing there, one would feel dizzy on looking downwards; the crows below look small like beetles; a man gathering herbs halfway down the rock looks as small as his own head; the fisherman walking upon the beach below appear like mice, and so on. This is such a vivid description that the audience, convinced of the fidelity of Gloucester's feelings, can easily relate to him.

\subsection{Chaos and Confusion}

Eating going wrong and humans behaving in animal like ways point to a chaos in their life. The dramatist has portrayed a sense of horror through the strong images of cannibalistic 'cuckoos', 'live eels' and others. 'Cuckhold' refers to a husband of an unfaithful wife. It is quite unclear to the audience if Goneril's treatment of her old father is justified until they are told through the Fool's imagery which also foretells some events by giving an interpretation of the relationship between father and daughters and their natures and shortcomings. The Fool uses food imagery as a linguistic strategy to declare the daughters' behavior towards Lear as monstrously greedy and Lear's as foolish in bequeathing power to them. This folly of Lear's triggered their vicious appetites that are likely to devour him, the kingdom, and themselves metaphorically.

The Fool's referring to the hedge-sparrow's feeding the cuckoo so long as to have its 'head bit off' by its young (I. iv, 222), is an allusion to the grotesque cannibalization of their step-parent. It pictures Lear's daughters in the horrifying act of patricide through consumption, triggered by an overindulgent father. It has obvious links to the children and parents in the plot and subplot in the play. The contrast of Goneril and Regan's treatment of their father despite being begotten, raised and empowered by Lear to those of the cuckoo who lays its eggs to be hatched in other birds' nests highlights the unnatural and worse nature of betrayal of parents by blood offspring. This enhances the effect of the ungratefulness of Goneril and Regan by an implied contrast to Edmund who was justified in feeling frustrated due to the law denying him inheritance and legitimacy.

When seen in the context of food theories, the Fool's metaphors of appetite applied to Goneril and Regan encompass appetite in its various forms - for food, sex, and 
power (Sparer 2009).The Fool's hedge sparrow and cuckoo passage combines the appetites for food and sex which food theorists have explained to be closely associated. Lukanuski (1998) contends that sex, like hunger, if not strictly controlled, leads to destruction of society, unknown fatherhood of children, no need for women to establish a family with one man, adults preying upon children and life sacrificed in pursuit of pleasure. Goneril and Regan demonstrate 'no need to establish a family with one man' as they both pursue affairs with Edmund. In an inversion of the play, the children prey upon the parents. Many lives-Lear's, Cordelia's, Gloucester's, even the daughters' own-are 'sacrificed in pursuit of pleasure.' Lack of governance of gustatory, sexual, and political appetites ultimately collapses the kingdom.

\subsection{Degeneration of humans}

Edgar, when talking as the Bedlam-beggar, makes many references to animals with no apparent symbolic meaning and sometimes, mentions certain animals for their typical qualities like: 'hog in sloth, fox in stealth, wolf in greediness, dog in madness, lion in prey'. Moreover, characters are described in terms of animals. As Bradley (1922) says, the souls of all the beasts seem to have entered the bodies of these mortals with their horrible venom, lust, savagery, sloth, deceitfulness, filthiness and cruelty.

The huge number of animal images gives us the feeling of 'humanity reeling back into the beast' (Spurgeon, 1935). They also help to enhance the feeling of horror and bodily pain and the resultant catharsis in the audience. In addition to savage wolves, there are tigers; darting serpents; detested kite; a sharp-toothed vulture; gnawing rats; stinging adders and insects; the baited bear; and whipped, whining, barking, mad and biting dogs painted through this imagery. All this aids in creating and enhancing the effect of an unprecedented ambience of physical pain and rapine cruelty.

\subsection{Sin and evil}

The unforgettable imagery of sin and evil appearing chiefly in the speeches of Lear during and after the storm has been employed to emphasize his internal plight. When the storm is blowing hard, Lear says that this is the time when gods can discover their enemies, and he mentions various kinds of sinners: the bloody murderer, the perjurers, the pretender to virtue, the incestuous man, the villain who conspires against the life of others and so on. When Lear puts his daughters on trial in the farm house, he feels that one of the criminals has been allowed to escape. He says: 'Corruption in the place! False justicer, why hast thou let her escape?' Subsequently, he talks about the flatterers who mislead and misguide a king, adultery and lechery which are rampant, the excessive and uncontrollable sexuality of women, the police constable's hypocrisy, the usurer sentencing a cheat to death and so on hinting at the evils and conspiracies in the English court. 
Linked with this imagery of sin and evil is the imagery of devils and demons. Edgar, in his role as the Bedlam-beggar, constantly speaks of being troubled and tormented by 'the foul fiend', leading him through fire and flame, ford and whirlpool, over bog and fen; putting knives under his pillow, and poison beside his soup, making him ride a horse, trotting over narrow bridges to follow his own shadow.

A little later, Edgar speaks of a devil that causes cataract and squint in his eyes (causing difficulty or inability to see through things, events and people) and who hurts the poor creatures of the earth and of the fiends of lust, dumbness, stealing, murder and grimacing hinting at factors affecting a person's judgment.

\subsection{Fierceness and brutality}

The images of fierceness and brutality have been used to enhance the intensity of feeling depicted by the characters typical of a Renaissance tragedy. In the very opening scene, when Lear loses his temper with Cordelia, he swears by 'the mysteries of Hecate and the night', and by 'all the operation of the orbs', that he will have nothing to do with her. He says that he would rather recognize the barbarous Scythian as his kith and kin than recognize Cordelia as his daughter. A moment later, he refers to Cordelia as 'unfriended, new adapted to our hate, dowered with our curse.'

When Lear, later, gets angry with Goneril, he utters a terrible curse upon her using imagery effectively expressing rage, fury and cruelty. He appeals to the Goddess Nature to render Goneril barren and infertile, to dry her reproductive organs, so that no child can ever come forth from her body. Similar fierce imagery is employed by Lear when, speaking to Regan, he calls upon lightening to scorch and burn the eyes of Goneril thus: 'dart your blinding flames into her scornful eyes.' (II, iv.186)

\subsection{Man's position in the chain of beings}

The recurrent imagery of clothes sheds light on man's position in the chain of beings in a philosophical manner. Lear's stripping Cordelia of all privileges and paraphernalia that befit royalty makes us ponder over the fact that it is the society which determines the social persona of every individual. If all human beings are stripped of all the clothing, nobody will be a king or a cobbler or anyone else. So, what differentiates human beings from one another is social persona. Lear and Cordelia best illustrate this point. Cordelia is the king's daughter, a prospective queen (after getting married), and a virtuous girl in her own right. But once divested of her position, love, possessions, privileges, authority, good public opinion, etc. for being tactlessly truthful, she is at the mercy of the whims of her suitors.

Philosophising on this aspect continues in the storm scene when Lear, after seeing a naked man, says, 'Is man no more than this?' The civilized man is contrasted 
with the essential man thus. As Lear says, man borrows his clothes from animals. Seeing the naked Bedlam-beggar, Lear says that this man represents the essential human being while he himself and his companions (Kent and the Fool) represent the sophisticated man, because the former has no clothes on, while they are wearing clothes investing them with individualities. The Bedlam-beggar, he says, 'owes no silk to the worm, no hale to the beasts, no wool to the sheep, and no perfume to the civet-cat'. Thus, the Bedlam-beggar is 'the thing itself, unaccomodated man is no more but such a poor, bare, forked animal', as the Bedlam-beggar is. But at the same time, he is a harmless creature. In an earlier speech, Lear points out the significant difference between the gorgeous clothing of a lady with the almost bare body of a poor man. In the scenes of madness, Lear emphasizes on the way clothes which symbolize distinctions of class and wealth also lead to a perversion of justice by saying that small vices appear through tattered clothes and robes and furred gowns hide everything. This imagery actually is a commentary on all the characters in the play, the society, as well as human nature.

As Lear gradually ceases to have contact with the outer world, he speaks less to communicate with others and more to express his inner state of mind. $\mathrm{He}$ repeatedly speaks of the patience he needs to endure his suffering. Lear represents the suffering man. His madness is the most shocking part of his suffering. Cordelia gives a vivid picture of her father describing him 'as mad as vexed sea', singing aloud, with all kinds of rank weeds and nettles used as crown. A little later, the mad Lear appears fantastically dressed in wild flowers and delivers several speeches with Gloucester and Edger as his audience which Edgar declares as 'matter and impertinency mixed'.

\subsection{Characterisation and Psychological Development}

The imagery of reason in madness is balanced with imagery of madness in reason. Imagery and its utilization by characters also serve as a classifying or grouping parameter in the play. The characters around Lear, viz., the Fool, Edgar and Kent speak a language rich in imagery. However, the wicked characters, Edmund, Goneril, Regan and Cornwall seldom employ images. These characters speak rationally and in a deliberate manner. Their language does not reveal to us what is taking place within them. They are the cool, calculating, unenlightened and unimaginative persons inept to use creative imagery. Their mundane priorities have rendered them incapable to relate to nature or to the elements. Their world is the world of reason. In this sense, they are representatives of the new political order. Moreover, chewing, biting and destroying animals signify different sins and the psychological conditions caused by sin and evil (Conter, 1986).

\subsection{Love vs. Justice}

The major characters of King Lear are revealed through several trial scenes, real as well as imagined. These scenes also draw parallels between two major themes, love 
and justice, as opposing entities that can hardly coexist. The audience judge King Lear for his poor judgment in his first love trial of his daughters. He demands an outward sign of respect and love. Cordelia's 'nothing' puts justice above love and the other daughters' false protestations further testify the stupidity of combining love with justice. In the next love trial, France's accepting the 'dow'rless daughter' declaring her 'beyond price' highlights the follies of Lear and Burgundy for believing in receiving rather than giving love and preferring worldly goods to love respectively.

In the storm scenes, when Lear perceives that he is denied the respect and love that he deserves, he is in quest for justice in a series of trial scenes where he himself is the judge, jury and executioner. He invokes gods to bring their enemies to the final bar of justice. He tells the guilty to 'tremble', 'hide' or 'shake' in pieces. However, in his new incarnation, he is cured of his madness through forgiveness and love. At this stage, Shakespeare dramatizes love, repentance and forgiveness in the garb of justice. In an imagined court scene, he sees Regan fleeing justice and shouts, 'False justicer, Why have you let her 'escape?' This can also be interpreted as meaning Lear's letting lose all the cruelties of the brutal daughters by his initial folly.

At subsequent stages of his learning, Lear seems to flee justice. The wise and transformed Lear, in the end, learns to put justice and love in their proper places. No irony is lost when we realize that this is precisely the message which drove him to mad fury in the beginning when Cordelia talks about the proper places of duty and love. He is turned gradually from a 'dragon in wrath', to a person 'more sinned against than sinning' to the ironical 'every inch a king' and lastly, a 'foolish fond old man' through a series of self-analyzing and enlightening trial scenes.

The sub-plot is also punctuated by trial scenes. The blinding of Gloucester and his subsequent indictment by Cornwall and the tiger-sisters, Goneril and Regan, also play out in the trial scene. Apart from the physical characters, the abstract moral qualities are also put on trial in the play. In the joint-stool scene, the sheer brutality of Cornwall and Regan puts justice itself on trial and in another scene, the lovelessness is placed on trial.

Trial by combat is another type of trial in King Lear. The major characters are put to trial in the middle of the combat scene. Albany arrests Edmund on the charge of "capital treason" and Goneril for being an accomplice. Edgar throws down a challenge to Edmund for restoring justice. When Edmund falls in the fight, he seeks to delay the fight 'by rule of knighthood'. Unlike the first scene, where all characters were brought on stage for the sake of a love test, in the last scene, we see a show of physical force against Edmund, Goneril and Regan because they are found out to be 'loveless' in the trial. Lear puts himself on a symbolic trial with the words spoken to Cordelia while asking for her forgiveness, 'Come, let's away to prison, We two alone will sing like birds i' th' cage.' Here, prison no longer 
symbolizes justice. Prison symbolizes repentance, forgiveness and reunion with Cordelia as a matter of choice.

To sum up, Lear's life has been the story of a trial in which he judges others and is, in turn, judged by others. Not only this, he also judges himself in a series of trial scenes and comes to an enlightenment regarding his self through deliberation on his circumstances and follies. The plot, Lear's character and the larger meaning of the play have been portrayed marvelously through imagery of justice used in trials.

\subsection{Binary opposites}

Being a poet of nature, Shakespeare presents binary opposites throughout the play(Tung, 2010).He makes use of imagery to show contrasts between Nature and human nature, physical and spiritual nature, good versus bad nature, natural versus unnatural, normal versus abnormal nature, and so on. Imagery also helps the playwright establish two identities of Lear in the play: the good, wise and unselfish versus the foolish and selfish one. Being true to the spirit of Renaissance, Shakespeare presents good prevailing over evil human nature in the play. This humanistic vision allows Shakespeare to juxtapose the principles of neoclassical moderation and morality with the Romantic principles of change and contrariety; unfallen nature of innocence and fallen nature of experience.

\subsection{Philosophical and political commentary}

Imagery is utilized by Shakespeare to provide philosophical and political commentary on character, plot, action and the general ambience of contemporary England and social conflicts of the time. It is provided by the wise fool characters (in the Renaissance or Shakespearean sense), the enlightened characters or those who undergo some enlightenment through the play (Sparer, 2009).

Scott (2000) declares the Seventeenth Century to be the most turbulent period in British History. King Lear, written between 1603 and 1606 and published in quarto in 1608, depicts the playwright's foresight and vision regarding the political scenario through the images used. Coinciding with the death of Elizabeth and accession of James1, Lear shows the results of a disagreeable succession(Hadfield, 2003) and also represents along with Gloucester, a feudal aristocracy threatened by a bourgeois class and the Tudor monarchs' struggle against maintenance and an armed entourage(Delany, 1977). In a nostalgic humanism, Shakespeare dwells on the Tudor crisis with Lear as a figure of the old aristocratic regime. It focuses on what can be improved and indirectly advises the king or those in position to do so. Direct representation was not possible due to the strict laws introduced by Elizabeth banning the discussion of succession. However, in literature, fundamental questions appeared in the form of mirror for princes' tradition guiding monarchs, hence the use of imagery to point to things about and to royalty in a disguised manner. 
Animal imagery is also used in relation to their alimentary habits for characterization and political commentary in the play, as Sparer (2009) suggests, e.g., the comparison of Goneril with birds of prey and 'the tiger, the cat, the boar, and the serpent' reveal her evil intentions and ingratitude toward her father.

As Sparer (2009) opines using food theories as its basis, the imagery of possession, consumption of, control over, ability to provide for food and even the choice of food and its quantity consumed has been used to depict economic, political, social and personal power, masculinity, femininity or the lack of these. It starts with the opening scene with Lear's use of the word 'digest' while referring to the one third of land once reserved for Cordelia while bequeathing his political power to Goneril and Regan. (I.i.128) Afterwards, Goneril and Regan's gluttony and insatiable appetites of all kinds and preying upon others, through imagery, signifies a threat to their exercise of power and hence to their and the kingdom's survival.

Goneril's refusal to feed Lear dinner initiates the King's emasculation through food, and this motif is emphasized by the Fool's images of empty 'egg shell' and the peasecod, as well as a knight's image of Lear as a starving animal, all of which allude to both political and male impotency and gradual degeneration. Similarly, images of gluttony and insatiability used for Goneril and Regan refer to their hunger for food, power and their desire for the illegitimate Edmund and make them appear less womanly and less human. In a broader sense, all these point towards the inversion of the social order, a chaotic state of affairs and prophesizes the great disturbance in their life which the audience and Lear cannot foresee yet. The images of 'cuckoos' and 'live eels' characterize Goneril and Regan to be as unnatural as fratricidal cannibals. They also refer to the Machiavellian undercurrent of the new power regime in the play as well as contemporary English politics which reflected the emergence of crass materialism.

In the egg riddle, the Fool explains to Lear how he can produce two crowns by cracking an egg and 'eating up the meat' himself. Sparer ( ) quotes Carol Adams stating: 'Meat eating demarcates individual and societal virility.' The Fool further suggests Lear having 'little wit' in his 'bald crown' when he gave his 'golden one away'. (I.iv.156 $\neg 164)$. Through this, he also points out to the inversion of the social order. By consuming the meat, the Fool becomes more powerful than the King, indicating he has also lost wits along with power. Soon after, the Fool uses the image 'shelled peascod' (I.iv.190) to refer to Lear. Starting from meat and egg i.e., food for the rich, and proceeding to peasecod i.e, food considered fit only for the poor in Shakespeare's time, the Fool symbolically points out towards Lear's emasculation, decreasing economic power, and social status.

The cuckoo and live eel metaphors imply that the daughters' treatment of Lear is monstrous in its greed. The passage's combination of animal and eating imagery is particularly striking because it pictures cuckoo fledglings engaged in the startling cannibalization of their step-parent, the hedge-sparrow. Political and Machiavellian 
suggestions are also embedded in the reference to cannibalism. This refers to the unnatural behavior of Goneril and Regan, Lear's biological offspring, who destroy their line of descent through their lies, ingratitude and unnatural betrayals.

Invoking the imagery of bread scraps, the Fool remarks to Lear he who keeps neither 'crust nor crumb ... shall want some' (I.iv.188-189) thus forewarning him of the consequences of his foolishness in prematurely bequeathing his kingdom to his daughters. This also indirectly advises the England monarch to refrain from unjustifiable bequeathing of land and authority.

The motif of cannibalism begins in the first scene when Lear banishes Cordelia saying: 'The barbarous Scythian', / Or he that makes his generation messes / To gorge his appetite, shall to my bosom/ Be as well neighbored, pitied and relieved, / As thou my sometime daughter' (I.i.117-120). Lear warns that he would treat Cordelia as he would treat a cannibal. This also refers to the contrast between good and evil, and appearance and reality when the Fool takes up the cannibalism reference and corrects it in the hedge-sparrow and cuckoo passage, re-configuring Goneril and Regan as the cannibals and Lear as the consumed. Later, Lear refers to his daughters as 'sea-monsters' (I.iv.253) preying upon human flesh according to mythology, and as 'detested kites'.

When cannibalism enters a society, relationships become suspicious; humans become food for each other; hierarchies overturn; and order turns to chaos. The Fool's implication of the daughters as cannibals predicts the dire consequences of their rule and their abuse of King Lear. This commentary on the nature of humanity through the image of cannibalism sheds light on the political meaning of the play. Critics have analysed the politics of the eleventh century King Lear and discussed how Shakespeare's version of King Lear comments upon the sixteenth century English politics. There was a shift in political structure followed by a rising commercialism: 'In this era, the old ethos is one of unreckoned generosity, magnificence and carelessness, whereas the new values stress providence, frugality, and even calculation. Lear and Cordelia talk in the language of free giving, while Goneril, Reagan and Edmund think quantitatively, they put a price on things, they ask coldly, "What need one?"' (27). Certainly, the rise of mercantilism pushed commercialism, ideals of providence, frugality, and calculation to the forefront.

The Fool uses imagery for characterisation, too. The Fool's imagery of the wanton eel knapping cook (II.ii.310-12) forewarns a horror in a humorous way. He draws a picture of a cook batting at eel heads pie while yelling at them. In an unnatural twist of the food chain, slithering eels rise in rebellion against their potential eater. The unnaturalness is even more horrific because the Fool delivers it with humour. Royal banquets mostly had eels in the menu, and many kings died from their overconsumption. Paradoxically, eels were a "condemned" food, due to their living in an "unwholesome atmosphere," their gummy texture, and their supposed 
spontaneous reproduction from rotting organic matter or decaying flesh. Their symbolic correlation to Lear's daughters suggests that while they have the potential to serve as royalty and have the outer embellishments of such, their natures are contrary to that.

Imagery also helps some characters establish their identities in the play. Cordelia describes her identity as distinct from her sisters through alimentary metaphor. Unlike Goneril and Regan, the unnatural 'consumers' as labelled by the Fool, she claims, she 'cannot heave' her heart into her 'mouth' (I.i.91-92) literally meaning she cannot find the words to express the depth of her love for her father and metaphorically, she cannot eat her flesh and blood like her sisters.

Kent uses imagery as part of his initial disguise to solidify his identity making him acceptable to Lear in his introduction: 'to fight when I cannot choose-and to eat no fish.' (I.iv.13-17)Foakes (1997)says that Kent 'may be signalling that he is a proper man, and eats only meat (Capell and Collins, 1779); or that he as a Protestant abstains from fasting on Fridays (Warburton, 1747); or all of these things'. Thus Kent, like Cordelia, differentiates himself from the 'consumers' and places himself into association with Lear and Cordelia, the starving characters.

The late sixteenth and early seventeenth centuries were marked by food shortage and bad harvests in England. The audience, like all the population, was afraid of food insecurities. Imagery used in King Lear to depict such themes as land and inheritance, food and its consumption, natural resources' management, plants and weeds enables audience to understand the changes in contemporary thinking about ecological relationships caused by a switch to early agrarian capitalism(Archer et al., 2012). Cordelia's references to her father's crown made of 'darnel' and other weeds refer to the contamination of crops, thus alluding to the strained relations between the crown and the subjects, legitimacy and illegitimacy, and the popular resistance to elite power. There are many other botanical images pointing to the food supply politics.

\subsection{Enhancing the tragic effect through depicting inner psychological trauma}

Acts 2-4 are the richest in imagery since they depict mainly what is happening to Lear and within Lear. The protagonist's inner trauma here is more important than the outer action. It is expressed through very expressive imagery that also helps to enhance the pathos of Lear's tragedy and hence the resulting catharsis among audience. The non-human world of nature enters the play in the same measure as the human world breaks down and falls to pieces. This happens when the father is expelled by his daughter, when the son is persecuted by the father, and when madness threatens the human order. Accordingly, the first Act contains little Nature-imagery; in the second act it begins to grow; and it reaches at its peak in the third and fourth acts showing us the forsaken Lear in madness. 
On the whole, we see that the imagery related to corporeal persecution persists till the end. Gloucester seizes the recurring theme of the tragedy and crystallizes it forever by drawing the picture of man being torn limb from limb into pieces by the gods as their sport, to whom they are but as 'flies to wanton boys'. Lear tells Cordelia he is bound 'Upon a wheel of fire', Edgar views the gods manufacturing instruments of torture to plague men with; and, in the end, Kent's farewell to his dead master's body, utilises the same metaphor:

$\mathrm{O}$, let him pass! He hates him

That would upon the rack of this tough world

Stretch him out longer. (V. iii, 380)

\section{Conclusion}

It can be said without exaggeration that imagery in King Lear provides a foundation or pillar on which the whole structure of the play stands. It plays the role of providing a commentary and in depth understanding of the plot, characterization, action, political commentary, enlightenment, purpose, chain of being, contemporary politics, a world view and much more to mention a few. It also helps characters to say what otherwise can't be said in the context and situation it was meant to be said. It also fulfills the purpose of helping audience from all sorts of social backgrounds relate to characters and events in the play. Hence, imagery caters to the understanding and imagination of all and sundry among the audience and helps to give a universal appeal to the timeless themes portrayed in the play. It also helps the play surpass all social, temporal and geographical boundaries.

\section{References and notes:}

Alex P, Brogan T and Warnke FJ. (1993) The new Princeton encyclopedia of poetry and poetics. Princeton: Princeton UP.

Archer JE, Turley RM and Thomas H. (2012) The Autumn King: Remembering the Land in King Lear. Shakespeare Quarterly 63: 518-543.

Bradley AC. (1922) Shakespearean Tragedy; Lectures on Hamlet, Othello: Macmillan and Company, limited.

Capell E and Collins J. (1779) Notes and Various Readings to Shakespeare: Notes and various readings, pt. 3 and 4. 1780: Henry Hughs.

Clemen W. (2013) The development of Shakespeare's imagery: Routledge.

David P. (1998) News Concreteness and Visual-Verbal Association Do News Pictures Narrow the Recall Gap Between Concrete and Abstract News? Human Communication Research 25: 180-201.

Delany P. (1977) King Lear and the Decline of Feudalism. Publications of the Modern Language Association of America: 429-440.

Durand G. (1999) The anthropological structures of the imaginary: Boombana Publications. Durand G, Chauvin D and Reis MJ. (1996) Campos do imaginário. 
Ellis-Fermor UM. (1980) Shakespeare's drama: Taylor \& Francis.

Foakes R. (1997) King Lear, ed. The Arden Shakespeare, third series (Walton-on-Thames: Thomas Nelson, 1997, repr. 2003).

Hadfield A. (2003) The Power and Rights of the Crown in Hamlet and King Lear:'The King - The King's to Blame'. The Review of English Studies 54: 566-586.

Hockey DC. (1959) The Trial Pattern in King Lear. Shakespeare Quarterly 10: 389-395.

Hockley WE. (2008) The picture superiority effect in associative recognition. Memory \& Cognition 36: 1351-1359.

Lukanuski M. (1998) A place at the Counter: The Onus of Oneness. Ron Scapp and Brian Seitz. Albany: SUNYP: 112-120.

Nadal MLB. (1994) METAFORA Y HUMOR. Metàfora i creativitat 1: 47.

Paivio A, Rogers TB and Smythe PC. (1968) Why are pictures easier to recall than words? Psychonomic Science 11: 137-138.

Scott J. (2000) England's Troubles: Seventeenth-century English political instability in European context: Cambridge University Press.

Sparer SR. (2009) The food of fools: An analysis of the Fools' gustatory imagery in "King Lear": Florida Atlantic University.

Spurgeon CF. (1935) Shakespeare's Imagery and what it Tells Us: Cambridge University Press.

Stenberg G, Radeborg K and Hedman LR. (1995) The picture superiority effect in a crossmodality recognition task. Memory \& Cognition 23: 425-441.

Tung C-h. (2010) The Two Lears: Shakespeare's Humanist Vision of Nature.

Warburton W. (1747) The Works of Shakespeare. London: J. and P. Knapton 1747. 


\title{
Summary
}

\section{Connotative Confluence: Imagery and its functions in Shakespeare's King Lear}

\author{
Shazia Aziz \\ COMSATS University Islamabad, Lahore Campus, Pakistan \\ Rabia Ashraf \\ Lahore College for Women University, Lahore, Pakistan
}

\author{
Huma Ejaz \\ COMSATS University Islamabad, Lahore Campus, Pakistan \\ Rafi Amir-ud-Din \\ COMSATS University Islamabad, Lahore Campus, Pakistan
}

\begin{abstract}
Written in the early 1600s, King Lear, an early modern tragedy with the human condition as its main premise, displays Shakespeare's effective exploitation of complex imagery. Through various images and extended or long drawn out metaphors, Shakespeare not only comments on character, plot, action, man's position in the universe in relation to Nature, offspring and siblings, but also addresses such questions as political legitimacy, treason, treachery, aristocracy and the relationship between land and the monarch. In a turbulent period marked by strict rules against commenting directly on politics and royalty even in the parliament, imagery also serves as advice for the monarch in the tradition of speculum principis i.e., mirror for princes literature. This paper discusses the effect and manifold functions of various imagistic techniques used in King Lear and how imagery as a stylistic tool helps the playwright to substantially expand the meanings of the play making it a timeless and universal reading not only for the learners of Literature, but also for historians, psychologists, political scientists, philosophers, economists and food theorists, to mention only a few.
\end{abstract}

Key words: Imagery, linguistic device, metaphors, similes, symbol, themes, pathos, catharsis, psychological trauma, extended metaphor 